\title{
O CÓDIGO DE PROCESSO PENAL BRASILEIRO E O SISTEMA ACUSATORIO IMPLEMENTADO PELA LEI N. 13.964/19
}

\author{
Lícia Jocilene das Neves ${ }^{1}$ \\ Escola Superior Dom Helder Câmara (ESDHC) \\ Raissa Cupertino Resende ${ }^{2}$ \\ Escola Superior Dom Helder Câmara (ESDHC) \\ Artigo recebido em: 20/07/2020. \\ Artigo aceito em: 22/10/2020.
}

\section{Resumo}

Em 24 de dezembro de 2019, após as devidas deliberaçóes do Congresso Nacional, foi sancionada pelo Presidente da República a Lei n. 13.964, com vacatio legis de trinta dias, correspondente ao pacote Anticrime do ex-Ministro da Justiça e Segurança Pública - Sérgio Moro. Entre as providências estabelecidas pela referida lei, inúmeras foram as alterações promovidas no Código de Processo Penal Brasileiro de 1941, ainda que alguns artigos alterados, mesmo após os 30 dias de vacância da lei, não estejam em vigor, por causa da suspensão provisória de suas implementaçôes, determinada pelo vice-presidente do Supremo Tribunal Federal - Luiz Fux. Nesse contexto, a presente comunicação tem por objetivo analisar o sistema processual acusatório adotado a partir da Lei n. 13.964/2019, bem como pretende-se responder ao seguinte questionamento: a criação da figura do juiz das garantias assegurará o sistema acusatório e a efetivação da imparcialidade do juiz julgador? Com a finalidade, portanto, de melhor abordar o tema proposto, serão utilizados o método indutivo e pesquisa bibliográfica, baseandose, essencialmente, nas doutrinas disponíveis sobre o assunto, no Decreto-Lei n. 3.689, de 3 de outubro de 1941, e na própria interpretação da lei sancionada. Ressalta-se que, ao se alterar o sistema processual, múltiplos são os reflexos observados em outros institutos como o inquérito policial, a ação penal e a prisão cautelar, institutos estes que também serão objetos de análise e sobre os quais, de alguma maneira, atuará o juiz das garantias.

Palavras-chave: juiz das garantias; pacote Anticrime; sistema acusatório.

1 Mestre em Direito e Instituiçôes Políticas pela Universidade FUMEC (FUMEC). Bacharel em Direito pela Pontifíca Universidade Católica (PUC-MG). Professora da graduação em Direito da ESDHC. ORCID: http://orcid. org/0000-0003-0653-3628 / e-mail: liciajocilene@gmail.com

2 Graduanda em Direito pela ESDHC. e-mail: raissacuper@hotmail.com 


\section{THE BRAZILIAN CRIMINAL PROCEDURE CODE AND THE ACUSATORY SYSTEM IMPLEMENTED $B Y L A W 13.964 / 19$}

\section{Abstract}

On december 24th, 2019, after following deliberations in National Congress, Law no.13.964, corresponding to Anticrime measures package from former Public Security and Justice Minister, Sergio Moro, was sanctionated by the Republic President and came into force after thirty days of its publication. Among of necessary arrangements applied by the law, several changes were introduced in the 1941 Brazilian Criminal Procedure Code, although some changed articles, even after the thirty days of its publication, haven't yet entered into force becouse of their implementation temporay suspension given by the Supreme Court vice-president Luiz Fux. In this regard, this communication intends to analyze accusatorial system implemented since Law 13.964/19. It also aims to answer to following question: will the warranties judge, created by Law 13.964/19, ensure the accusatorial system application and the impartiality of the case judge? Within the present document restricts, it will be conducted a bibliographical research based on available legal doctrines on the subject, the Decree-Law 3.689 from October 3rd, 1941, in addiction of own interpretation of sanctioned law using an inductive research method. It must be highlighted that however the procedural system changes, several impacts shall be observed in others criminal procedural institutes such as police inquest, criminal action and preventive detention. Also, these institutes will be subjects of the present research on which somehow warranties judge shall act.

Keywords: accusatorial system; Anticrime package; warranties judge. 


\section{Introdução}

Em fevereiro de 2019, quando o então Ministro da Justiça e Segurança Pública, Sérgio Moro, propôs o pacote Anticrime na tentativa de diminuir a impunidade criminal no Brasil e de aperfeiçoar o Código Penal, o Código de Processo Penal e a Lei de Execuçáo Penal, inúmeras foram as críticas dos operadores do Direito quanto à ausência de estudo e debate sobre as alteraçóes pretendidas mediante a implementação do pacote.

Contudo, durante todo o ano de 2019, tramitou no Congresso Nacional o projeto de lei que combinava o texto original proposto pelo ex-Ministro com outro texto proposto, em 2018, pelo Ministro do Supremo Tribunal Federal, Alexandre de Morais, culminando com o sancionamento da Lei n. 13.964, em 24 de dezembro de 2019, pelo presidente da república, determinando ainda vacatio legis de trinta dias. Apesar de muitas mudanças objetivarem estabelecer ainda mais a cultura do encarceramento e alguns dispositivos apresentarem inconstitucionalidade, as críticas não somente se referem ao texto da lei, mas, também, ao escasso prazo para se implementar as mudanças ocorridas no Código de Processo Penal, principalmente, no que se refere ao sistema processual e à criação e efetivação da função do juiz das garantias em todo o território brasileiro, alteraçóes essas que são objeto de análise do presente artigo.

Ressalta-se que as mudanças necessárias na justiça brasileira, nas mais variadas comarcas existentes no território brasileiro, são de tal proporção, que o próprio vice-presidente do Supremo Tribunal Federal, Ministro Luiz Fux, decidiu pela suspensão da vigência dos artigos que tratam ou são alcançados pela implementação do juiz de garantias, bem como de suas funções, até que a Ação Direta de Inconstitucionalidade, ADI 6.298/DF, movida pela Associação dos Magistrados Brasileiros e Outros seja julgada pelo plenário do STF.

Nesse contexto, com o objetivo de uma melhor abordagem do tema proposto, mediante a utilização do método de pesquisa indutivo e da pesquisa bibliográfica, qualitativa e descritiva, dividiu-se o artigo em dois tópicos. Inicialmente se descreverá os sistemas processuais penais inquisitivo, acusatório e misto, demonstrando as diferenças entre cada um deles e o que deverá ocorrer no Código de Processo Penal (CPP), visto que a Lei n. 13.964/19 alterou o sistema brasileiro de misto (conforme entendimento de alguns doutrinadores como será verificado adiante) para acusatório. Seguidamente, o segundo tópico tratará da inovação no $\mathrm{CPP}$ trazida pela referida lei no que se refere à criação da figura do juiz das garantias e suas funçóes, apesar de que a presença de um juiz que atuasse na fase investigativa, de modo a garantir o contraditório, a ampla defesa e a imparcialidade 
do juiz julgador, já fosse um anseio antigo dos operadores do Direito. Salienta-se que também neste tópico seráo objeto de análise outros institutos do Direito Processual Penal Brasileiro alcançados pela lei, como o inquérito policial que sofrerá sua judicialização; a ação penal no que se refere ao recebimento da denúncia, bem como sua rejeição que não mais será ato do juiz julgador de modo a garantir sua imparcialidade; a prisão cautelar que, na fase investigativa, deverá ter averiguada a legalidade da prisão em flagrante não mais por um juiz de custódia, mas, sim, pelo juiz das garantias, bem como a prisão preventiva não mais poderá ser decretada de ofício, ainda que fosse possível, anteriormente à Lei n. 13.964/19, somente na fase processual. Igualmente se dissertará sobre a tramitação do processo visto que esta será alterada por causa funçóes que exercerá o juiz das garantias.

Após a abordagem dos tópicos suprarreferidos, pretende-se responder ao questionamento inicial sobre o fato da criação e efetivação do juiz de garantias, que de alguma maneira, consolida ou não a implementação do sistema acusatório, para entáo se concluir o artigo.

\section{Os sistemas processuais penais}

No âmbito penal, o processo é o único instrumento de exercício da função jurisdicional pelo Estado, pois não se admite a autocomposição ou a autotutela de direitos, vez que o Direito Penal abrange a tutela de bens jurídicos pelo Estado, que uma vez violados e tratando-se de uma conduta típica, ilícita e culpável, tem-se um crime cuja ocorrência provocará a atuação estatal.

Nas palavras de Barros (2002), em um Estado Democrático de Direito, “a solução dos conflitos deve ficar a cargo do Estado como ente forte e imparcial”, quando a resolução não puder ser feita por meios alternativos como conciliação, mediação e arbitragem. Tem-se, assim, não somente um processo como um instrumento de exercício da Jurisdição, como também, no âmbito do Direito Processual Penal, o caminho necessário para se chegar à aplicação da pena e sua execução, bem como "o instrumento de garantia do indivíduo em face do Estado" (PACELLI, 2017, p. 19).

O Estado, portanto, exerce o que se denomina de "pretensão punitiva" que consiste na função e no dever de investigar, processar e punir aquele que, supostamente, realizou uma conduta proibida por lei. Assim, o processo penal assegura que esses atos sejam realizados de maneira adequada, respeitando os direitos fundamentais, como a dignidade da pessoa humana, o contraditório e a ampla defesa, entre outros.

Os atos de persecução penal: investigar, processar, julgar e punir, quanto 
às formalidades se desenvolvem e se baseiam única e exclusivamente na lei, em respeito ao princípio da legalidade, e foram pensados sob a lógica de um sistema processual, diretamente relacionado à "posição ocupada pelo juiz" (LOPES JUNIOR, 2017, p. 156). Nesse aspecto, os sistemas processuais penais são classificados doutrinariamente como inquisitório, acusatório ou misto, os quais serão devidamente descritos a seguir.

\subsection{0 sistema inquisitório}

A principal característica desse sistema reside no acúmulo de funções do juiz, já que ele fica responsável por investigar, acusar e julgar. Há, então, a figura do ativismo judicial, na medida em que o magistrado detém a iniciativa da produção de provas. Segundo entendimento de Moreira e Camargo (2016), no sistema inquisitório, "não há livre convencimento na sentença, porque o juiz que realizou investigaçôes e formulou a acusação já parte de sua íntima convicção formada e, ao atuar dessa maneira, está muito propício a condenar o réu”. É clara e notória nesse sistema a parcialidade do magistrado quanto ao caso concreto a ser julgado, não condizendo com o que se almeja de um julgador.

No que diz respeito às provas produzidas, é necessário ressaltar que havia um sistema de hierarquia entre elas, ou seja, cada prova detinha uma valoração específica, sendo a confissão a maior delas, denominada, inclusive, como "rainha das provas". Nesse sentido, preconiza Lopes Junior (2017, p. 172):

Tendo em vista a importância da confissão, o interrogatório era visto como um ato essencial, que exigia uma técnica especial. Existiam cinco tipos progressivos de tortura, e o suspeito tinha o "direito" a que somente se praticasse um tipo por dia. Se em 15 dias o acusado não confessasse, era considerado "suficientemente" torturado e era liberado.

Ressalta-se que no sistema inquisitório não havia, por exemplo, o princípio da vedaçáo à prova ilícita, já que a tortura era um dos instrumentos utilizados para se alcançar a confissáo. Outros princípios também se faziam ausentes quais sejam: o contraditório, a ampla defesa e a imparcialidade do juízo.

Evidencia-se, entấo, que o sistema inquisitório, como bem lecionado por Lopes Junior (2017, p. 173), "foi desacreditado - principalmente - por incidir em um erro psicológico: crer que uma mesma pessoa possa exercer funções tão antagônicas como investigar, acusar, defender e julgar”. Por isso, torna-se imprescindível a análise do sistema acusatório, suas características e efeitos no Código de Processo Penal. 


\section{$1.2 \mathrm{O}$ sistema acusatório}

Contrariamente ao sistema inquisitório, o sistema acusatório separa todas as funçôes exercidas durante a persecução penal, ou seja, sua principal característica é diferenciar aquele que investiga, acusa, defende e julga. A iniciativa de produção de provas não cabe mais ao juiz e sim às partes, permitindo, assim, a imparcialidade do julgador. O magistrado, em tese, não tem mais convicção pré-constituída a respeito do acusado, pois não é ele quem vai atrás das provas que justifiquem seu entendimento, pelo contrário, cabe, agora, à acusação - enquanto detentora do ônus probatório - influenciar seu convencimento de que o acusado náo é inocente.

Sobre o sistema acusatório, Lopes Junior (2019, p. 47) menciona que:

É importante destacar que a posiçâo do "juiz" é fundante da estrutura processual. Quando o sistema aplicado mantém o juiz afastado da iniciativa probatória (da busca de ofício da prova), fortalece-se a estrutura dialética e, acima de tudo, assegura-se a imparcialidade do julgador.

O magistrado não mais decide baseado em um sistema de valoração de provas, mas, sim, seu convencimento é baseado no princípio da persuasão racional, que determina que ele seja formado de maneira livre, motivada e fundamentada. A confissão perde, portanto, sua característica de rainha das provas, bem como não pode ser a única utilizada para condenar o acusado, já que se entende que ela pode ter sido obtida de maneira ilegal e, por isso a necessidade de sua produção em juízo e valoração segundo as demais provas produzidas.

Ademais, o processo penal, no sistema acusatório, é condicionado a diversos princípios e um deles é a plenitude de defesa que traz em seu significado a ampla defesa associada à defesa técnica, ou seja, o acusado pode se utilizar de todos os meios de prova admitidos no Direito, inclusive o de permanecer em silêncio, e é indispensável que ele seja assistido por um advogado ou defensor público correspondendo à defesa técnica.

Portando, mediante o sistema acusatório, entende-se que o processo penal lida com um bem jurídico muito importante que é a liberdade do acusado e, por isto, é necessário que haja mecanismos como a separação das funçôes, que inibem qualquer interferência negativa numa futura decisão, pois, como leciona Pacelli (2017, p. 32), “o risco de condenação de um inocente há de merecer muito e maiores cuidados que o risco da absolvição de um culpado”.

Embora os sistemas inquisitório e acusatório sejam tão diferentes, há, ainda, 
um terceiro sistema que agrega características de ambos. Trata-se do sistema misto, a ser descrito na sequência.

\section{$1.3 \mathrm{O}$ sistema misto}

No sistema misto, segundo o entendimento de Nucci (2016, p. 76), há a "divisão do processo em duas fases: a instrução preliminar, com elementos do sistema inquisitivo, e a fase de julgamento, com a predominância do sistema acusatório".

Entretanto, conceituar determinado sistema com base, apenas, na divisão em que se preceitua a persecução penal, não demonstra a real característica do sistema misto, até mesmo porque a lógica desses sistemas processuais é demonstrar como os atos são praticados ao longo do procedimento.

Na visão de Lopes Junior (2017, p. 351) "não é necessário classificarmos um sistema como sendo misto, pois não existe mais sistema inquisitivo ou sistema acusatório puros, sendo todos, portanto, mistos”. Portanto, torna-se necessário, na verdade, identificar qual a essência dos atos de determinado sistema processual penal, para então classificá-los, levando em conta que tal análise não deve ser feita somente com base na existência ou não da separação inicial das funçóes, como mencionado por Lopes Junior (2017, p. 351), pois a referida separação "deve se manter ao longo de todo o processo, sem exceçóes, para que a estrutura de tal sistema não se rompa”. Por isso se estabeleceu a relação entre o sistema processual brasileiro e a lei sancionada recentemente.

\section{Sistema Processual Penal brasileiro e a Lei n. $13.964 / 2019$}

A Constituição Federal de 1988, em seu art. 129, concedeu ao Ministério Público a função de "promover, privativamente, a ação penal pública" (BRASIL, 1988), bem como assegurou, pela primeira vez, diversas garantias ao acusado como ampla defesa, contraditório, presunção de inocência, entre outras características de um sistema acusatório.

Entretanto, até o ano de 2019, não havia entendimento unânime na doutrina quanto à classificação do sistema processual penal brasileiro. Alguns doutrinadores, como Tourinho Filho (2017), afirmavam que o processo acusatório era impuro, mitigado e temperado, pois mesmo que houvesse a separação de quem investiga, acusa e julga a lei processual penal, em algumas situaçóes, dava ao juiz poderes instrutórios complementares como, por exemplo, do art. 156, do Código de Processo Penal que determina: 
Art. 156: A prova da alegação incumbirá a quem fizer, sendo, porém, facultado ao juiz de ofício:

I: ordenar, mesmo antes de iniciada a ação penal, a produção antecipada de provas consideradas urgentes e relevantes, observando a necessidade, adequação e proporcionalidade da medida (BRASIL, 1941).

No entendimento de Nucci (2015) o sistema processual utilizado seria o misto, sob a justificativa de que na fase pré-processual prevalece o sistema inquisitivo visto que a investigação preliminar fica a cargo da Polícia Judiciária, sob a fiscalização do Ministério Público e nessa fase não há contraditório nem ampla defesa, enquanto na fase processual, em si, o sistema seria o acusatório.

Em contrapartida, na concepção de Lopes Junior, como já citado anteriormente, todos os sistemas, atualmente, são classificados como mistos, não existindo mais um sistema totalmente puro. Ademais, o supracitado autor afirma que em sua essência, o sistema brasileiro é inquisitório, pois detém inúmeras características desse sistema, mesmo que a Constituição demarcasse, por meio de princípios, “a adoção do sistema acusatório" (LOPES JUNIOR, 2017, p. 186).

Com a vigência da Lei n. 13.964/2019 a discussão sobre o sistema processual penal brasileiro chega ao fim, pois o art. $3^{\circ}$, A, do CPP determina que "o processo penal terá estrutura acusatória [...]” (BRASIL, 1941), acarretando, portanto, mudanças significativas quanto ao modo de se pensar e desenvolver a persecução penal.

Nesse contexto, para que o sistema acusatório seja realmente adotado, é preciso que se entenda que a iniciativa do juiz (quanto a certos atos) é vedada não só na fase investigatória como também na fase processual, a fim de manter sua imparcialidade.

O processo penal brasileiro, até a vigência da Lei n. 13.964/19, permitia que fosse dado ao magistrado um poder para além de sua função de julgar. Alguns juízes presidiam o processo como coadjuvantes do Ministério Público - principal autor das açóes penais - já que lhes era dada a possibilidade de realizar alguns atos "de ofício" que, na verdade, deveriam ser requeridos pelo órgão acusador ou pela própria defesa, sob a lógica do sistema acusatório.

O art. 311, do Código de Processo Penal (1941), por exemplo, previa que a prisão preventiva, durante o curso do processo penal, poderia ser decretada de ofício pelo juiz. Era dada ao magistrado, portanto, uma função aquém da sua, já que ele não julgava um pedido de prisão e sim a decretava sem análise de nenhum pedido. Com o advento da Lei n. 13.964/2019, a prisão preventiva, em qualquer hipótese, seja durante o inquérito policial ou no curso da ação penal, somente 
será decretada mediante requerimento do Ministério Público, querelante e assistente ou por meio de representação da autoridade policial. Observa-se que, por se tratar de uma reforma parcial, ou seja, feita diretamente somente sobre alguns dispositivos do Código de Processo Penal, necessária se faz a releitura de muitos outros que não foram alterados e que se tornaram, automaticamente, contrários ao sistema acusatório.

Nessa lógica, não é mais possível, por exemplo, que o juiz converta de ofício a prisão em flagrante em preventiva, conforme o art. 310, II, do Código de Processo Penal (BRASIL, 1941). Em primeiro lugar, porque tal ideia desrespeita o art. 282, $\$ 2^{\circ}$, segunda parte, do CPP que determina que no curso da investigação criminal, as medidas cautelares só poderão ser decretadas "por representação da autoridade policial ou mediante requerimento do Ministério Público" (BRASIL, 1941). Igualmente, sob a lógica do sistema acusatório da Lei n. 13.964/2019, permitir tal atuação do juiz de ofício significa violar de maneira clara a separação existente entre as funçôes: julgar e acusar. Portanto, a conversão também teria que ser feita mediante pedido daquele que exerce função de acusador no processo penal.

O art. 156, I, do Código de Processo Penal (BRASIL, 1941), que antes era a justificativa de alguns doutrinadores para denominar o nosso sistema como acusatório mitigado, também não pode mais prosperar, pois ao magistrado, mais uma vez, se permitiria atuar como coadjuvante do Ministério Público, ao lhe dar poderes probatórios. Nessa mesma lógica, o art. 209, caput, do Código de Processo Penal (BRASIL, 1941), também deve ser relido, pois permite que o juiz ouça "outras testemunhas, além das indicadas pelas partes”, sendo isto atividade probatória exercida pelo julgador, mais uma vez, contrária ao sistema acusatório.

Portanto, não há mais que se falar, de uma vez por todas, na busca pela "verdade real", uma vez que náo cabe ao juiz perseguir a verdade no processo penal, em nenhum momento da persecução. A figura do magistrado é julgar o caso concreto com base naquilo que lhe é apresentado pela acusação e pela defesa e, caso o parquet não seja capaz de provar, com absoluta eficácia a culpa do acusado, não cabe ao juiz produzir provas e, sim, absolver com base no princípio da inocência e do in dubio pro reo. Bem argumentado é o ponto de vista de Lima (2017), ao afirmar que:

Não se pode atribuir ao processo penal a missão de buscar a verdade real ou substancial, pois a verdade não é fundante no processo penal democrático e acusatório. A decisão judicial, portanto, não é reveladora da verdade, qualquer que seja, material ou formal, mas sim um ato de convencimento, formado em contraditório e nos ditames do devido processo legal. 
Nessa perspectiva, como bem mencionado por Lopes Junior (2017, p. 179)):

Não basta termos uma separação inicial, com o Ministério Público formulando a acusaçáo e, depois, ao longo do procedimento, permitir que o juiz assuma um papel ativo na busca da prova ou mesmo na prática de atos tipicamente da parte acusadora [...].

Finalmente, revela-se também necessária a releitura do art. 385, do Código de Processo Penal (BRASIL, 1941), tão criticado pela defesa, vez que permite que o juiz condene o acusado mesmo que o Ministério Público, órgão acusador, tenha postulado pela absolvição. Isto constitui nítido retrocesso ao sistema inquisitório e deverá ser repelido do sistema processual penal brasileiro, vez que se trata agora de um sistema acusatório como será a seguir descrito.

\subsection{O juiz das garantias, o sistema acusatório e o processo penal}

Diretamente ligado à noção de um sistema acusatório, aduz-se, também, o que foi denominado pela Lei n. 13.964/2019 de juiz das garantias, figura criada pela própria Câmara dos Deputados, no processo de aprovação do pacote Anticrime.

O juiz das garantias não é uma inovação do Direito Processual Penal brasileiro, pois diversos países como França, Itália, Espanha, Portugal, Chile e Colômbia, entre outros, conforme menciona Maya Machado (2018), adotam a mesma noçáo trazida pela Lei n. 13.964/2019, de que para que haja uma imparcialidade plena no processo penal, é necessário que haja a presença de dois juízes, um responsável pela fase de investigação e outro pelo efetivo julgamento.

Nessa perspectiva, nos moldes do ar. 30- B, do Código de Processo Penal (BRASIL, 1941), "o juiz das garantias é responsável pelo controle da legalidade da investigação criminal e pela salvaguarda dos direitos individuais [...]”. Portanto, entre as responsabilidades de um juiz também se observarão: o controle da legalidade da prisão em flagrante e da prisão preventiva; ser informado das investigaçóes e controlar os respectivos prazos; julgar o habeas corpus impetrado antes do oferecimento da denúncia; receber a denúncia ou rejeitá-la etc. O juiz das garantias, nesse aspecto, atuará na fase pré-processual impedindo, de certo modo, que o magistrado responsável pelo julgamento do acusado na fase processual, não seja induzido inconscientemente por decisóes anteriores que cabiam também a ele tomar.

Corroborando o entendimento supracitado, Rogério Tadeu, procurador regional da república aposentado, menciona que: 
Não basta que a autoridade julgadora não esteja subjetivamente atrelada a situaçốes de impedimento ou suspeição, devendo-se exigir daquele magistrado, outrossim, que não pairem dúvidas sobre a sua imparcialidade em relação a outros aspectos. [...] A parcialidade objetiva surge mediante um forte prejulgamento que faz o juiz, em cognição, para adoçáo de medida cautelar na investigação: garantia real, prisão cautelar, busca e apreensão, por exemplo. Essa cognição será horizontal, sobre questôes, ou ainda vertical, sobre o fundo do Direito (TADEU, 2013, p. 2).

A figura do juiz das garantias amplia, por conseguinte, a noção de imparcialidade do julgador, desvinculando-o, pelo menos em parte, do que é denominado pela doutrina de dissonância cognitiva. Essa teoria da dissonância cognitiva, formulada pelo psicólogo social Leon Festinger (1957) e estudada por Andrade (2019) e Ritter (2016), resumidamente, menciona que o ser humano diante de duas opiniốes contrárias se sente desconfortável - mesmo que inconscientemente -, e tende, portanto, segundo palavras de Schunemann (2012, p. 9) a "obter relaçôes harmônicas entre seu conhecimento e suas opiniôes”, seja pelo efeito perseverança, seja pelo princípio da busca seletiva de informaçóes.

Para Lopes Junior (2014), quanto ao efeito perseverança, cabe afirmar que:

[...] seria um mecanismo de autoconfirmação de hipóteses, superestimando as informaçôes anteriormente consideradas corretas. Já a busca seletiva é quando procura-se, predominantemente, informaçōes que confirmam a hipótese que em algum momento prévio foi aceita, gerando o efeito confirmador-tranquilizador.

Como bem mencionado por Andrade (2019, p. 6), "a pessoa procura eliminar ou diminuir a dissonância mais pela mudança de atitudes pessoais do que pelo abandono da crença ou da opinião anterior". A referida teoria, destarte, pode ser observada no âmbito do processo penal, na medida em que o magistrado trabalha a todo o momento com opiniōes divergentes (acusação e defesa) e, nesse aspecto, torna-se necessário descrever como se desenvolve o processo.

\subsection{A tramitaçáo do processo}

Instrumentalmente, o processo penal se desenvolve a partir de uma inicial acusatória oferecida pela parte autora denominada queixa-crime - em açáo penal privada - ou denúncia - em ação penal pública. Posteriormente, com base nos indícios de autoria e materialidade, elementos geralmente colhidos no inquérito 
policial e devidamente apresentados na denúncia ou queixa-crime, tem-se uma decisão interlocutória em que o magistrado decide se irá receber ou não a inicial acusatória. Nesse momento, é possível que o juiz forme alguma convicção quanto ao caso concreto, já que é o primeiro momento em que ele tem contato com o fato ocorrido, além do que, essa convicção pode estar intimamente ligada ao posicionamento jurídico da acusação, já que não lhe é apresentada, nesse mesmo momento, alguma tese defensiva.

No decorrer do processo pode, ainda, o magistrado ter de decidir sobre a decretação de prisão preventiva, de sua manutenção ou mesmo, da aplicação de medidas cautelares diversas da prisão nos termos do art. 282, do CPP (BRASIL, 1941), o que, mais uma vez, torna-o parcial ao caso. Consequentemente, pode-se supor que um pré-julgamento, às vezes inconsciente, é formado a partir dessas decisões. Corroborando esse fato, Andrade (2019, p. 16) aduz:

Como o juiz não é uma máquina, o trabalho feito em sede de cognição sumária acaba por influenciar - e isso é natural - a formulação da cognição plena, mas jamais pode determinar o resultado do processo. Se ele ficar vinculado a sua pré-compreensão, olvidando que decidiu com base na aparência do direito alegado, num momento em que o acusado não teve chance de se manifestar, desprezando completamente suas provas, não julgará com imparcialidade.

Nesse contexto, Schunemann (2012) realizou um estudo demonstrando exatamente essa lógica da dissonância cognitiva, ao comparar dois tipos de julgamentos: aqueles proferidos por magistrados que tiveram contato prévio com o inquérito policial e aqueles que apenas conheceram do caso concreto no momento do julgamento. Após inúmeras análises, foi possível observar que os juízes que detinham algum pré-conhecimento dos autos, por meio da investigação, como mencionado por Schunemann (2012, p. 14) "não notaram e não retiveram o conteúdo defensivo produzido na audiência de instrução e julgamento", pois somente se recordavam "das informaçôes incriminadoras, por eles já conhecidas e constantes do inquérito". Igualmente, Lopes Junior (2014) afirma que:

O juiz, ao receber a denúncia e posteriormente instruir o feito, passa a ocupar - de fato - a posição de parte contrária diante do acusado que nega os fatos e, por isso, está impedido de realizar uma avaliação imparcial, processar as informaçóes de forma adequada. Grande parte desse problema vem do fato de o juiz ler e estudar os autos da investigação preliminar (inquérito policial) 
para decidir se recebe ou não a denúncia; para decidir se decreta ou não a prisáo preventiva; formando uma imagem mental dos fatos para, depois, passar à "busca por confirmação" dessas hipóteses na instrução.

No que se refere à fase pré-processual, ou seja, à fase investigativa, o inquérito policial é um procedimento administrativo e informativo mediante o qual se objetiva colher elementos que embasarão a inicial acusatória. Uma das teses utilizadas exaustivamente pela defesa no processo penal se fundamenta no 155, caput, 2a parte, do Código de Processo Penal (BRASIL, 1941) que prevê que o juiz não pode "fundamentar sua decisão exclusivamente nos elementos informativos colhidos na investigação". Esse dispositivo é claro ao determinar que o juiz sequer deveria utilizar, mesmo que como complemento, os atos de investigação para fundamentar sua decisão, pois esses atos não foram submetidos ao contraditório, devendo o juiz se pautar somente nas provas produzidas. Entretanto, na prática, muitos juízes, mesmo sabendo do mencionado artigo, se alimentam do que foi produzido na investigaçáo policial quando, durante o julgamento, não são produzidas provas capazes de confirmar seu entendimento, segundo lição de Lopes Junior (2017).

Resta, assim, evidenciado um exemplo da dissonância cognitiva, pois "O juiz que vai atrás da prova, primeiro decide (definição da hipótese) e depois vai atrás dos fatos (prova) que justificam a decisão (que na verdade já foi tomada)" (LOPES JUNIOR, 2017, p. 188), ou seja, antes do julgamento os juízes são capazes de formar uma pré-convicção, mesmo que inconscientemente, justamente pelo contato anterior com os autos do inquérito. Sobre essa questão, o referido autor ainda menciona que:

A fraude reside no fato de que a prova é colhida na inquisiçẫo do inquérito, sendo trazida integralmente para dentro do processo e, ao final, basta o belo discurso do julgador para imunizar a decisão. Esse discurso vem mascarado com as mais variadas fórmulas, do estilo: a prova do inquérito é corroborada pela prova judicializada; cotejando a prova policial com a judicializada; e assim todo um exercício imunizatório (ou, melhor, uma fraude de etiquetas) para justificar uma condenação, que, na verdade, está calcada nos elementos colhidos no segredo da inquisição (LOPES JUNIOR, 2017, p. 177).

Ainda em referência ao juiz das garantias, o art. $3^{\circ}, \mathrm{C}, \$ 3^{\circ}$, do Código de Processo Penal (BRASIL, 1941), determina que a atuação do referido magistrado 
terminará com o recebimento da denúncia, sendo que os autos do inquérito não mais acompanharáo os autos principais, ficando sob custódia do juiz das garantias. Portanto, com a Lei n. 13.964/2019, o juiz de instrução e julgamento não mais terá acesso aos atos de investigação, exceto quanto às provas consideradas irrepetíveis.

A existência, por conseguinte, do juiz das garantias coloca fim à contaminação a qual os juízes estavam sujeitos ao se vincularem à investigação policial, bem como ao realizarem algum tipo de ato decisório que não fosse o julgamento, efetivando-se o princípio supremo da imparcialidade do juízo de uma vez por todas. Nesse aspecto, afirma Miller (2019):

Quanto ao reforço da imparcialidade da jurisdiçấo criminal, não se desmerece o esforço de todos os juízes para julgar com imparcialidade - é da deontologia de sua função e de sua própria vocação. Mas é intuitivo que a falta de contato prévio com a formaçáo da prova e da justa causa propicia ao juiz que julgará o mérito condiçôes de se desinvestir dos resultados processuais até então alcançados.

Por mais que as alteraçóes no Código de Processo Penal promovidas pela Lei n. 13.964/2019 representem um progresso para boa parte dos juristas, há quem tenha ficado insatisfeito com tais modificaçốes.

A Associação dos Magistrados Brasileiros (AMB, 2019), por exemplo, publicou em nota pública a preocupação com relação ao instituto do juiz das garantias, sobre o argumento de que isto traria elevados custos ao Poder Judiciário, vez que sua implementaçáo dependeria da "criaçáo e provimento de mais cargos na Magistratura”. Entretanto, como bem argumentado por Miller (2019):

A implementaçáo do juiz das garantias não exige a criaçáo de cargos de juiz, mas a adoção de formatos e critérios inovadores de fixaçâo de competência. Na França e na Alemanha, por exemplo, a competência para o juízo das garantias incumbe a órgãos de segundo grau (Tribunal de Grande Instance e Landsgericht); embora não seja passível de replicação no Brasil sem alteração constitucional, essa solução evidencia o equívoco de imaginar que a implementação do juiz das garantias exija a criaçáo de órgão judicial próprio em cada comarca e subseção judiciária.

Contrariando o posicionamento da $\mathrm{AMB}$, por meio de nota técnica sobre a estruturaçáo e implementaçáo do juiz de garantias e do julgamento colegiado pela primeira instância, o Colégio Nacional dos Defensores Públicos Gerais (CONDEGE, 2019) afirma: 


\begin{abstract}
A imediata estruturação do juiz de garantias ao cotidiano forense pátrio não exige grandes mudanças ou aumento de custos financeiros, apenas a aplicação de regra entronada na legislação processual penal desde a edição do Código vigente, qual seja impedido o juiz natural, seu substituto (juiz tabelar) seguirá na condução do processo após o recebimento da denúncia.
\end{abstract}

O Conselho Nacional de Justiça (BRASIL, 2020), no que lhe concerne, sabendo dos impactos que tais mudanças causariam em todo o sistema processual penal brasileiro, instituiu um grupo de trabalho - nos termos da portaria n. 214/2019 - no intuito de demonstrar quais as repercussóes que a Lei n. 13.964/2019 traria, bem como para analisar possíveis sugestôes conferidas mediante consulta pública sobre como melhor atender aos dispositivos da lei que tratam do juiz das garantias.

O Ministro Dias Toffoli (BRASIL, 2020), tendo consciência de todas as questôes que envolvem as modificaçóes no art. $3^{\circ}, \mathrm{C}, \$ 3^{\circ}$, do $\mathrm{CPP}$, suspendeu, mediante liminar, a vigência dos dispositivos que tratam do juiz das garantias por 180 dias, sob a justificativa de que sua inserção "enseja completa reorganização da justiça criminal no país", e que esta não poderia ser feita somente no prazo de vacatio legis (que teve fim no dia 23 de janeiro de 2020).

Posterior à liminar supramencionada, o Ministro Luiz Fux, ao assumir provisoriamente a presidência do Supremo Tribunal Federal, em razão de Toffoli ter saído de recesso, optou por cassar a liminar, suspendendo, por fim, o instituto do juiz das garantias por tempo indeterminado (BRASIL, 2020). Essa indeterminação do período necessário para se reestruturar o Poder Judiciário traz uma insegurança jurídica ao Processo Penal Brasileiro e seus juristas, pois a suspensáo não atingiu somente a figura do juiz das garantias, mas também a afirmação de que o sistema processual penal adotado é o acusatório. Esta é uma questão delicada e que não deveria ter sido decidida por um único Ministro, na medida em que há inúmeras questôes a serem analisadas e aplicadas.

\title{
Consideraçóes finais
}

Em 23 de janeiro de 2020, quando entrou em vigor grande parte dos artigos alterados no Código de Processo Penal Brasileiro em virtude da Lei n. 13.964/2019, o sistema processual penal que, anteriormente era classificado como misto - pelo menos por parte da doutrina - passou a ser o acusatório. Isto significa que não mais haverá uma fase pré-processual inquisitiva e, sim, duas fases - a investigativa e a processual - no sistema acusatório.

Entretanto, a alteração no sistema somente é observada com a judicialização 
da fase investigativa no Direito Processual Penal Brasileiro que, até entáo, caracterizava-se como um sistema inquisitivo. Isto significa que na referida fase investigativa predominava a figura daquele que preside o inquérito, que colhe os elementos quanto à materialidade do crime e quanto aos indícios de autoria sem que seja dada, em tese, à parte contrária, o direito ao contraditório e à ampla defesa. Ocorre que com a alteraçáo no sistema processual para acusatório também a fase investigativa há de se modificar, ou seja, há a judicialização do inquérito policial, o qual passa ao controle judicial, pois qualquer inquérito que seja instaurado indicará imediatamente ao juiz que este não mais será o que julgará o caso na fase processual, mas outra autoridade judicial que a Lei n. 13.964/2019 denominou de juiz das garantias.

Nesse contexto, a criação da figura do juiz das garantias também foi uma das principais alteraçóes provocadas pela lei no sistema processual brasileiro, pois passa-se a ter uma autoridade judicial que ficará responsável por tudo decidir antes que se inicie o verdadeiro julgamento do crime e de seu autor, garantindo, assim, a imparcialidade daquele que deverá atuar na fase processual, o qual se denomina juiz julgador e também o contraditório e a ampla defesa à parte que, até então, se submetiam aos atos da autoridade policial. Ressalta-se também que, com o advento da Lei n. 13.964/2019, os autos do inquérito ficarão sobre a custódia do juiz das garantias não mais se juntando aos autos do processo. Dessa maneira, pretende-se assegurar que o juiz julgador não tenha contato com os elementos referentes à investigação e não mais seja influenciado seu convencimento com o que foi colhido antes de sua atuação.

Faz-se necessário mencionar que as alteraçóes no sistema processual e a criação do juiz das garantias impactaram outros institutos do Direito Processual Penal Brasileiro além do inquérito policial, como também a ação penal e as prisões cautelares, principalmente no que se refere à verificação da legalidade da prisão em flagrante e na decretação da prisão preventiva tanto na fase investigativa quanto na fase processual, como já devidamente apresentado no presente artigo.

No que se refere ao questionamento que se pretendeu responder quanto ao fato de o juiz das garantias ser uma maneira de se garantir a imparcialidade do juiz julgador e de se afirmar o sistema acusatório, pode-se afirmar que, assim que os artigos que foram afetados pela criaçáo dessa nova autoridade judicial entrarem em vigor, em virtude da suspensão temporária de sua vigência, pode-se afirmar que sim. Essa confirmação se deve ao fato de o juiz julgador não mais se ver envolvido na fase investigativa, pois não mais terá que decidir sobre prisão preventiva na fase investigativa, não mais terá que decidir sobre qualquer ilegalidade relativa aos atos da autoridade policial ou das diligências que foram realizadas ou não e, principalmente, não será mais sugestionado pelos próprios autos do inquérito 
policial.

No que concerne à garantia do sistema acusatório, pode-se afirmar que a existência de um juiz que atuará na fase investigativa exercendo um controle judicial, assegurando o contraditório e a ampla defesa da parte indiciada e também assegurando, ainda que em tese, a separação das funçôes de investigar, defender, acusar e julgar, visto que náo se tem como efetivamente evitar possíveis conjecturas entre o juiz julgador e a acusação. Levando em consideração os dados levantados, a medida é positiva em relação aos objetivos pretendidos com a implementação da Lei n. 13. 964/2019. Pode-se afirmar, portanto, que a referida lei atendeu a antigos anseios dos operadores do Direito Penal e Processual Penal que há tempo observavam a necessidade da náo contaminaçáo do convencimento do juiz julgador pelos elementos colhidos na fase investigativa, assegurando, assim a imparcialidade dessa autoridade e o devido processo legal.

\section{Referências}

ABREU, T. Juiz das garantias: uma análise objetiva acerca dos desafios e dos avanços da nova figura jurídica no Direito Penal brasileiro. Migalhas, 10 jan. 2020. Disponível em: https://www.migalhas.com.br/depeso/318233/juiz-das-garantias-uma-analise-objetiva-acerca-dos-desafios-e-dos-avancos-da-nova-figura-juridica-no-direito-penal-brasileiro. Acesso em: 1 mar. 2020.

AMB - ASSOCIAÇÃO DOS MAGISTRADOS BRASILEIROS. Nota Pública: Juiz de garantias, 25 dez. 2019. Disponível em: https://www.amb.com.br/nota-publica-juiz-de-garantias/?doing_wp_cron=1586871596.60204005241394042 96875. Acesso em: 14 abr. 2020.

ANDRADE, F. S. A dissonância cognitiva e seus reflexos na tomada da decisão judicial criminal. Revista Brasil de Direito Processual Penal, Porto Alegre, v. 5, n. 3, p. 1651-1677, set./dez. 2019. Disponível em: http://www.ibraspp.com.br/revista/ index.php/RBDPP/article/view/227. Acesso em: 17 jul. 2020.

BARROS, A. M. Processo penal segundo o sistema acusatório. v. 1. São Paulo: LED, 2002.

BRASIL. Conselho Nacional de Justiça. Portaria n. 214, de 26 de dezembro de 2019. Institui Grupo de Trabalho para elaboração de estudo relativo aos efeitos da aplicação da Lei n. 13.964/2019 nos órgãos do Poder Judiciário Brasileiro. Brasília, DF: CNJ, [2019]. Disponível em: https://www.cnj.jus.br/wp-content/ uploads/2019/12/portaria214.pdf. Acesso em: 14 abr. 2020. 
BRASIL. Conselho Nacional de Justiça. Release sobre a consulta pública sobre Juiz das garantias. Brasília, DF: CNJ, 2020. Disponível em: https://www.cnj.jus.br/ wp-content/uploads/2020/01/Release-questiona\%CC\%81 rio-Juiz-de-garantias-21-jan.pdf. Acesso em: 14 abr. 2020.

BRASIL. [Constituição (1988)]. Constituição da República Federativa do Brasil. Brasília, DF. Presidência da República, [2020]. Disponível em: http://www.planalto.gov.br/ccivil_03/constituicao/constituicao.htm. Acesso em: 23 abr. 2020.

BRASIL. Decreto-Lei n. 3.689, de 3 de outubro de 1941. Código de Processo Penal. Brasília, DF: Congresso Nacional, [2019]. Disponível em: http://www. planalto.gov.br/ccivil_03/decreto-lei/del3689compilado.htm. Acesso em: 1 mar. 2020 .

BRASIL. Supremo Tribunal Federal. Medida cautelar na ação direta de inconstitucionalidade 6.298/DF. Cuida-se de ação direta de inconstitucionalidade, com pedido de liminar ajuizada pela Associaçáo dos Magistrados em face de dispositivos da Lei n. 13.964, de 24 de dezembro de 2019, que alteraram o Código de Processo Penal (CPP), especialmente quanto à instituiçáo do "Juiz das Garantias" Brasileiros. Relator: Ministro Luiz Fux, 22 de janeiro de 2020. Disponível em: http://www.stf.jus.br/arquivo/cms/noticiaNoticiaStf/anexo/ADI6298.pdf. Acesso em: 1 mar. 2020.

CONDEGE - COLÉGIO NACIONAL DOS DEFENSORES PÚBLICOS GERAIS. Nota técnica sobre a estruturação e implementação do juiz das garantias e do julgamento colegiado pela primeira instância. Brasília/DF, 13 jan. 2020. Disponível em: http://www.condege.org.br/publicacoes/noticias/defensores-publicos-gerais-juiz-de-garantias-e-avanco-civilizatorio. Acesso em: 14 abr. 2020.

LIMA, D. A utópica e falaciosa busca da verdade real no processo penal. Canal Ciências Criminal - JusBrasil, 9 jun. 2017. Disponível em: https://canalcienciascriminais.jusbrasil.com.br/artigos/467739087/a-utopica-e-falaciosa-busca-da-verdade-real-no-processo-penal. Acesso em: 17 jul. 2020.

LOPES JUNIOR, A. Um processo penal para quê(m)? Análise do fundamento, natureza jurídica, sistemas processuais e objeto. Sistemas processuais penais: inquisitório, acusatório e o (ilusório) misto. In: LOPES JUNIOR, A. Direito Processual Penal. São Paulo: Saraiva, 2019. p. 44-54.

LOPES JUNIOR, A. Jurisdição penal. A posição do juiz como fundante do sistema processual. In: LOPES JUNIOR, A. Fundamentos do Processo Penal - Introdução Crítica. São Paulo: Saraiva, 2017. p. 155-206. 
LOPES JUNIOR, A. Teoria da dissonância cognitiva ajuda a compreender imparcialidade do juiz. Consultor Jurídico, 11 jul. 2014. Disponível em:https:// www.conjur.com.br/2014-jul-11/limite-penal-dissonancia-cognitivaimparcialidade-juiz. Acesso em: 5 abr. 2020.

MAYA MACHADO, A. Outra vez sobre o juiz de garantias: entre o ideal democrático e os empecilhos de ordem estrutural. André Maya Advocacia e Compliance, 2018. Disponível em: http://andremaya.com/blog/wp-content/uploads/2018/09/ Outra-vez-sobre-o-juiz-de-garantias-IBCCRIM.pdf. Acesso em: 1 mar. 2020

MILLER, M. Juiz das garantias é avanço e pode fortalecer cultura de imparcialidade. Consultor jurídico, 27 dez. 2019. Disponível em: https://www.conjur.com. br/2019-dez-27/marcello-miller-juiz-garantias-fortalece-cultura-imparcialidade. Acesso em: 5 abr. 2020.

MOREIRA, E. R.; CAMARGO, M. L. Sistemas processuais penais à luz da Constituição. Revista de Direito Constitucional e Internacional, São Paulo, v. 97, n. 4, set./out. 2016. Disponível em: http://www.mpsp.mp.br/portal/page/portal/documentacao_e_divulgacao/doc_biblioteca/bibli_servicos_produtos/bibli_boletim/ bibli_bol_2006/RDConsInter_n.97.05_1.PDF. Acesso em: 6 mar. 2020.

NUCCI, G. S. Sistemas de processo penal. In: NUCCI, G. S. Manual de processo penal e execução penal. 13. ed. Rio de Janeiro: Forense, 2016. p. 75-80.

PACELLI, E. O processo penal brasileiro. In: PACELLI, E. Curso de processo penal. Sáo Paulo: Atlas. 2017. p. 17-23.

RITTER, R. Imparcialidade no processo penal: reflexóes a partir da teoria da dissonância cognitiva. Dissertação (Mestrado) - Faculdade de Direito, Pontifícia Universidade Católica do Rio Grande do Sul, Porto Alegre, 2016.

SCHUNEMANN, B. O juiz como um terceiro manipulado no processo penal? Uma confirmação empírica dos efeitos perseverança e correspondência comportamental. Tradução José Danilo Tavares Lobato. Revista Liberdades, Sáo Paulo, n. 13, p. 30-50, set./dez. 2012. Disponível em: http://www.revistaliberdades.org. br/site/outrasEdicoes/outrasEdicoesExibir.php?rcon_id=140. Acesso em: 5 abr. 2020 .

TADEU, R. R. O juiz inquisidor no Brasil: um confronto com o sistema acusatório. Portal da Justiça Federal do Rio Grande do Norte. Natal: JFRN, 15 fev. 2013. Disponível em: https://www.jfrn.jus.br/institucional/biblioteca-old/doutrina/ Doutrina303-o-juiz-inqusidor-no-brasil.pdf. Acesso em: 5 abr. 2020.

TOURINHO FILHO, F. C. Manual de processo penal. 17. ed. São Paulo: Saraiva, 2017. 